\title{
Poetry as Eternal Voyaging: In Conversation with Theo Dorgan
}

\section{Pilar Villar-Argáiz}

\section{(2) OpenEdition \\ 1 Journals}

\section{Electronic version}

URL: https://journals.openedition.org/etudesirlandaises/10182

DOI: 10.4000/etudesirlandaises. 10182

ISSN: 2259-8863

\section{Publisher}

Presses universitaires de Caen

\section{Printed version}

Date of publication: 31 December 2020

Number of pages: $35-53$

ISBN: 978-2-84133-996-9

ISSN: 0183-973X

\section{Electronic reference}

Pilar Villar-Argáiz, "Poetry as Eternal Voyaging: In Conversation with Theo Dorgan", Études irlandaises [Online], 45-2 | 2020, Online since 31 December 2020, connection on 14 November 2022. URL: http:// journals.openedition.org/etudesirlandaises/10182 ; DOI: https://doi.org/10.4000/etudesirlandaises. 10182

\section{cc) (ㅇㅇ}

Creative Commons - Attribution-NonCommercial-ShareAlike 4.0 International - CC BY-NC-SA 4.0

https://creativecommons.org/licenses/by-nc-sa/4.0/ 


\section{Poetry as Eternal Voyaging: In Conversation with Theo Dorgan}

This conversation with Irish poet Theo Dorgan was carried out on 9 November 2019, on occasion of his visit to Granada for the performance in this city of the music/poetry show "Loco por Lorca: An Irish Celebration of the Great Spanish Poet". This audiovisual performance - featuring a creative exchange between music, words and poetry - had already premiered successfully in Madrid in 2018, and afterwards it was showcased in various places across Ireland, also to great critical acclaim. It was only a matter of time before the show was brought to Granada - Lorca's birthplace, his physical and emotional hometown, also the place of his death - thus the best place in which to honour him. Thanks to the institutional support of the Embassy of Ireland, and to the enthusiasm of the Ambassador Mrs. Sile Maguire, "Loco por Lorca" was performed on 7 November 2019 at the Centre Fundacion Federico García Lorca, perhaps the most prestigious literary centre in Granada and currently a cultural benchmark in the city. On the following day, a shorter version was enacted at the Faculty of Arts of the University of Granada. New translations into English and Irish of Lorca's poetry were read respectively by Keith Payne and Theo Dorgan; all this was accompanied by new musical compositions and arrangements of Spanish and Irish folk music by Cormac Juan Breatnach, Cormac de Barra, Jaime Muñoz, and Carlos Beceiro. The following conversation with Dorgan was held on a sunny, cold morning, before he returned to Ireland, and after two intense days celebrating Lorca. Dorgan revisits his long career as a poet and talks at length about issues that he has rarely addressed before, such as the interplay between poetry and politics, his communal conception of art, the literary influences that have shaped his work, the "other whereness" impulse he has always felt since he was a child and his fascination for Greek myth, among other things. This interview sheds new light into one of Ireland's most prolific (and also paradoxically underrated) poetic voices at present, an artist who, throughout his long career, has invested much of his energy in promoting other poets and tirelessly working for poetry and the arts in general.

Pilar Villar-Argáiz: There seems to be an evolution in your work. Your initial collections draw more on Russian landscapes; your more recent work on Greece. Similarly, this seems to be the case of literary influences. Russian poets such as Pushkin, Mandelstam, and Akhmatova are in the background of many of your 
poems in The Ordinary House of Love $(1990)^{1}$ and Rosa Mundi (1995) ${ }^{2}$. Later, modern Greek poetry is more clearly present from Sappho's Daughter (2001) ${ }^{3}$ onwards. The poetic voices which seem to resound more powerfully are those of Constantine Cavafy, George Seferis and Katerina Anghelaki Rooke, among others.

Theo Dorgan: My fascination with Russia and Greece has to do with my fascination with the "other place". I was always a dreaming child; I was always dreaming myself "other where". I think it was probably my interest in politics as much as poetry that pulled me towards Russia for a while. What I liked about Pasternak, Tsvetayeva, Akhmatova and Mandelstam was that they each navigated, in different ways, between a personal sensibility and a sense of what was happening in the world. I have always been drawn to the tensions of poetry and politics; I cannot ignore politics. These poets found each a particular voice, a voice for private reflection in a public idiom. I was drawn towards this. And then, I began to travel a lot; I have been travelling to Greece for the last thirty years or more, and I feel more and more at home there. (It is probably as my bones are getting older that I like being in the heat more.) I started going to Russia in 1986 for the Moscow film festival, when I was Director of the Cork Film Festival, and I was fascinated by how coded all the language was. Everything was a code, as I found out in conversations with Savva Kulish, the filmmaker, who became a good friend. There was the surface of Soviet life and underneath it there was a very different language of life, and I was fascinated by that, the doubleness of things. I suppose in a way something similar is happening in Greece, because even though we read in the newspapers that Greece is in a terrible crisis, they still sit outside in the cafés, smoking, drinking, arguing and falling in love. The economic life in the city is terrible, but in the islands where I go they have reverted to a mix of cash-and-barter economy. The son of a friend was getting married and he had no money. All of a sudden, somebody decided to get a terrace cleared; somebody wanted some vines planted; somebody needed a wall rebuilt; and somebody needed a house painted. And then he had the money for the wedding.

PVA: This is something that you have commented on elsewhere: your fascination for this sense of micro community in the Greek islands...

TD: I have a book coming out next month [December 2019] in Greek. The translator is called Socrates. You are there in a village taverna and somebody calls the waitress “Aphrodite!", "Persephone!". So just through the names you drop 4,000 years back into the classic world. There is the sense of an enduring Greece in the day-to-day and the same thing through the myths that come through; they keep this sense of endurance. It is as if time is suspended.

1. Theo Dorgan, The Ordinary House of Love, Galway, Salmon Publishing, 1990.

2. Theo Dorgan, Rosa Mundi, Galway, Salmon Publishing, 1995.

3. Theo Dorgan, Sappho's Daughter, Dublin, Wave Train Press, 1998. 
PVA: This reminds me somehow of those powerful lines taken from Michael Hartnett's "A Farewell to English", which you read at the end of the "Loco por Lorca" show on Thursday night: "Poets with progress / make no peace nor pact./ The act of poetry/is a rebel act" 4 .

TD: I read that as an imperative rather than as a descriptive phrase. He is not saying that poets don't make a peace or pact; he is saying "do not make peace or pact with this illusory kind of progress". It is an imperative, an order, not a descriptive phrase. It is an address to the poet.

PVA: So you sustain the view of poetry as an act that can foster social transformation...

TD: In a sense poetry (by which I also mean theatre and music at its best) is always a rebel act, not for the sake of being contrarian, but because the narratives of those in power (whether it is educational power, or political power, or medical power) are not to be absolutely trusted. You must question them. And the way to question them is through the language. I have been saying for twenty years or more (and now it's become a cliché in Ireland) that I was born into a Republic and later found out that I had become an item in an economist's spreadsheet. I used to be a citizen and now when I walk into a public hospital, there is a desk that says "Customer Information". I am not a customer in my hospital; I am a patient or a visitor, but not a customer! The principle duty of the poet is to keep language clear. To keep the spring clear. If there is a public role for poetry this is what it consists of, keeping language always fresh and meaningful.

PVA: Indeed, your literary influences are certainly inspired by writers who defend this view of art: Greek poets such as Cavafy, Irish poets such as Hartnett. In general terms, you seem to be inspired by poets more from outside of Ireland, than from within Ireland... Or am I wrong in this impression?

TD: I am not entirely sure because I have never entirely considered this question, to be honest. The reading becomes part of the furniture of my mind certainly. Whatever sensibility I have acquired through the years is not particularly Irish, but I don't think it is non-Irish either. Of course I am steeped in the Irish tradition, but my portable library, so to speak, is eclectic. In the Irish way of discursive conversation, we talk on and on and on, which may explain why the first draft of a poem I'm writing is always far too long. I do a lot of paring back. To be honest, I barely think of the influences I may have acquired. I am just interested in trying to write the next poem. I feel a sense of empathy with certain poets in Ireland. I really like Paula Meehan; she is obviously my life partner but I really liked her poems long before I met her. I am drawn to that lyric sensibility which is very clear about class and other political issues, about power and the abuse of power. I like the certain lightness of spirit in Moya Cannon. Thomas McCarthy is - I think - largely

4. Michael Hartnett, “A Farewell to English”, in Collected Poems, Peter Fallon (ed.), Oldcastle, The Gallery Press, 2001, p. 82. 
undervalued as a poet; he is probably my oldest friend in poetry. We met when we were eighteen in University College Cork. I do like Michael Hartnett a great deal, and I have come to feel closer to Seamus Heaney, probably as I get older. Heaney was an adult before my generation was adult. We were born into an idea of "youth generation", and Heaney had settled into himself by the time he was thirty. There was a steady note from his thirty onwards and I am now beginning to feel a sense of kinship with that sense of steady note. John Montague would also be an influence when I was a younger poet in two senses.

\section{PVA: Montague was your professor, right?}

TD: Yes. He was an influence in two senses. He brought from the American poet Robert Duncan the idea of shaping a collection of poems to make a book. So you don't just put down forty poems that are linked thematically or linked in terms of the sound patterns or points of view. You assemble or shape a book so that other bits reflect of each other; I learnt that from Montague. I also learnt some sense of leaping quality in the lyric; that you can leap from image to image, or from mood to mood rather than laboriously assembling the steps, from one stage to the next. I also learnt from Montague that what I didn't want from life as a poet was vanity, envy, anxiety about reputation. We saw these things in him and learnt the pitfalls to avoid (I am referring to Thomas McCarthy and myself although there were other poets around). We went down to visit him in his house and he was incredibly generous to us. He had a great library of mid-century American poetry and we could borrow whatever we liked from him as long as we liked. He was very generous in that sense; but he was always watching other people's reputations. He was always trying to arrange it that a collection would be reviewed by somebody who would be sympathetic and so on; and he'd have in his house all these letters from poetry journals from India, California or Chicago; they were at the hall table but back in the kitchen would be the electricity bill or the gas bill. He was trying to give a particular impression of the poet. He was a good exemplar in all these senses, unconsciously in this last sense. There are poets who have the delusion of a career in poetry; they worry about getting a poem into specific prestigious journals, they want to be reviewed by " $x$ " rather than by " $y$ "; and this, I'm sorry, I find it pathetic. You don't have a career in poetry, except by accident; you have a life in poetry. Poetry is eternal voyaging. I know that people would describe this is as a hopelessly romantic view, but there is nothing romantic about poverty and the neglect that very often accompanies the idea of life as an adventure. We are here to be witnesses; to witness what it is to be corporeal, to have bodies, to be among others; to be in this extraordinary world which is endlessly fascinating; and to be aware of the pain and the suffering of others; and to pay attention and to witness it. Poets just happen to be people whose act of witnessing comes out in words...

PVA: So you are talking about the role of the poets as being witnesses and their ability to create empathy. 
TD: I don't think it is a role. I want to be clear about this, Pilar, in case this may be misleading. I don't think of this in terms of duty to others, or to the world, or to the Republic. I am a citizen of the Republic, and I have certain moral and civic responsibilities as a citizen, but as a poet, I live in the "World of One". There is only one single unique witnessed sensibility. As I embrace the craft, I have a duty to the craft; I have an obligation to the individual poem, not to some grandiose idea of poetry. My obligation is always only to the poem I am working on and when it is gone or finished, or I have to let it go because I cannot do more work on it, my next obligation is to the next poem.

PVA: Now that you were talking about being a citizen of the Republic, I am thinking about this powerful poem you wrote on the occasion of the referendum on repealing the $8^{\text {th }}$ amendment of the Constitution in 2018, "Speaking Direct to the Camera" 5 , where - to my view - you powerfully rewrite the aisling tradition, in this chance encounter with "A young woman who knew no fear" and who offers "her art to set me free"...

TD: Amazing. None of that would have occurred to me...

PVA: I love this poem... And it is beautiful the way it finishes, with the resounding lines "I had forgotten my country/ until my country remembered me". You are a deeply committed poet; and have written extensively in prose on the need to rewrite the Constitution and the need to go back to the original roots of the Republic. Uniting that with Ireland's current situation and what is happening nowadays in Europe (and indeed the rest of the world), how would you define Ireland nowadays? Do you think the concept of the Republic needs to be reinvented? Would you say Ireland is a democracy?

TD: Well, of course, Ireland is a democracy in the normal everyday sense: we have free elections and there is no actual forceful coercion on anybody. But we have a state class now; and more and more the citizen is simply expected to obey, and vote every three or four years for preselected candidates chosen by the local branches of a party; and the local branch of the party acts according to what the hierarchy of the party wants; and that hierarchy inevitably reflects the view of people who are obsessed with having power, so the vote now has a very diluted impact. That is common among all the democratic countries. But you cannot function unless it is a representative democracy. Look at the extraordinary mess the British have made by giving the imperative to a single-issue referendum without taking care to ensure that everybody was fully and properly informed. But my primary question to all people who seek political power is "What is your option for the poor?". And if I don't get a satisfactory answer, then I automatically put them on the other side of the line. My father worked in a factory all his life, and so did my mother until she married. We were a large family. We were poor; we were not impoverished as

5. Shared by the poet on Facebook. 
there was always food on the table, but there was always only "just enough". I was conscious of that. I was conscious when I went to school that the teachers had no ambitions for the children from my "barrio"; the really bright ones might just get jobs as civil servants or as teachers, otherwise they simply didn't care. I was eight or nine and I was imagining I was travelling the world as a famous writer. From reading, I had a very large horizon; I could see the petty indignities visited on the poor all through my life. The expression of contempt from people with power had a very deep impression on me.

PVA: Is it still like that today? Can you talk about an impoverished working class community in Ireland?

TD: Well, the "working class" is a contested political term nowadays, because we obviously no longer have blocks. Employment has become fluid, and the methods of employing people have also become fluid. I have no nostalgia for the politics of the 1950s where you had the left, the middle, and the right. It isn't like that now; it is much more fluid. But there is also a more insidious kind of politics now, where increasingly the marvellous abstraction of the market is the dominant force in all the Western democracies. I don't want to live in an economy; I want to live in a Republic, where the first question asked in all public initiatives is "How would this impact on the human being?". So someone talks about making savings by concentrating hospitals, and I say "What about a woman who lives in a small village, whose husband is dead and she is a widow and she depends on an increasingly contracting public transport to get to a hospital?". So we ask the wrong questions. Instead of asking "How much can we save having fewer but bigger hospitals?", we should be asking "How much are we making life worse for the people those hospitals are being built for?". So the hospital becomes an end in itself, not the service that provides for public health. We look at it through the wrong end of the telescope. The four principles of the French Republic which I think are the central expression of Republican politics are "Liberty", "Equality", "Fraternity" ("Sorority") and Laïcité. Everybody forgets the fourth pillar: Laïcité, the removal of the religious imperative from the apparatus of the state, so that the neutral law becomes the pillar of the state. What we had in our quasi-republic, for a very long time, was more or less a theocracy.

PVA: But it is not like that anymore...

TD: No; it is crumbling; but the internal lines for the distribution of power remain very much the same. The people belonging to the first generation after independence, those who went into public service, had no problem with that idea of serving the public. Now, we have to conform to what suits the civil servant, and, in the words of Thomas Hobbes, the English philosopher, it is "a war of each against each". Imagine if there were constitutional rights for the land, for the air, for the water, for the environment. If the environment has a right not to be contaminated, it has implications for the industrial development, for fracking, for mining... 
PVA: This reminds me of the title of one of your collections, What this Earth Cost Us $(2008)^{6}$...

TD: Yes, this line is from Mandelstam. One thing all the great religions have in common is that they propose an idea of heaven; and this idea is dangerous because it suggests that we don't really have to worry about suffering, or about genocide, because we are all going to heaven anyway, so it avoids responsibility. But if you turn to art, you are foregoing the idea of heaven. Art is about growing up and taking responsibility...

PVA: Going back to the issue of politics, isn't Ireland a better country than the one you were brought up in?

TD: It is in certain senses, but where it is not a better country is that the idea of social compact has fragmented. By material standards, it is a better country, in legal terms it is a better country: women have more rights; we have equal rights; we have the removal of the constitutional ban on abortion. It is also better in terms of the weakening of the power of the Catholic church and the Protestant churches on education. The dark hegemonic force of the Catholic church has obscured the (much more minor, but equally true) domination of forms of social organisation by Protestant churches. When we look at the institutional abuse by the Catholic church, we tend to ignore the much lesser but still real presence of such abuse in Protestant institutions like the Bethany Homes. But, going back to my point: we are moved by a perfect neo-liberal agenda, which controls the economy for current state capitalism by giving a melioration of social circumstances. Irish people are now free to get an abortion or to get married if they are gay, but they are not free to buy a house. Some are trapped in a job which is increasingly meaningless and their workplace does not permit unions. We are paying more and more taxes for less efficient public transport. Hospital services are getting worse and worse, and there is less and less efficient public health. We are driven into the arms of private health insurances but we are still paying taxes for a public service, and we have surgeons operating privately in public hospitals. So everything is breaking down in terms of the social compact because people are becoming increasingly desperate to create a space in which to breathe as human beings, a space in which to read poetry, to listen to music, to make music, or simply to sit and talk in a spirit of amity with their neighbours. When your neighbour becomes your competitor, that is a very dangerous and destabilising moment, not just in a state, but in a whole culture...

PVA: It destroys solidarity altogether...

TD: Precisely. That is probably the place where my disposition towards politics and poetry come together. When I make a poem, I hope I have reflected something of what somebody else might have felt about being alive and human in this moment. I hope that I may be reaching down into the past to express solidarity with someone

6. Theo Dorgan, What this Earth Cost Us, Dublin, Dedalus Press, 2008. 
else who was in awe at the feeling of simply experiencing the sea on her face as she dived into the water. This is the accumulated, collected, human experience I am interested in, of which I consider myself an instance.

PVA: Thus your act of "reimagining" myth and ancient stories in your daily life...

TD: Absolutely. To me imagining is experiencing. It is a failure of the protected imagination of the poem if the reader does not go there, doesn't feel it; doesn't smell it, doesn't taste it, doesn't touch it. It is a failure of the craft, if I haven't managed to capture the imagining. The problem with imagining is that it is linked easily with a "matched image". For me, to imagine involves all the senses, so when I imagine the garden, I am only doing it properly if you can smell the resin from the tree trunk, or the dust under your feet, or if you can hear the birds, or hear the silence. It is creating a third dimension, even a fourth dimension to space. And it is a very ordinary power that we all have. The power of imagination is very real and very strong. Coleridge in the Biographia Literaria says that the imagination is an actual shaping power; it is an actual power. And that was the theme of my MA Thesis; its title was "The Image Fixed in Energy: Poetry in the Imaginal Domain". I was interested in the "Where is the where of the poem?". In Sufism, there is the idea that between the domain of the material forms and the domain of the intellectual forms (that is, numbers, alphabets, algorithms), there is a middle domain which the great French Islamologist Henri Corbin calls "the imaginal", in which the true products of the imagination are actually in the world. You cannot say they are not in the world. If you read Hamlet and if you feel sorrow for poor Ophelia, you are being sorry, in your actual life in real time, for "someone" who must in some sense actually exist, because we don't think about things that are not there. The daemons in Hieronymus Bosch's paintings were real to the people who believed in hell and daemons. True imagination can bring things into the real world. Coleridge distinguishes between secondary imagination (which is the ceaseless recombination of fixities and definites so as to produce pleasing patterns) and the primary imagination (the participation in the finite world of the infinite I am; the agent imagination). This primary imagination is part of the process of being and becoming. True imagination is that you are on the deck of the Argo as it is approaching the clashing rocks. I occasionally teach workshops and I usually say to the young writers: "Your first job is to take me there; I want to be there; absolutely there". This is what is all about: amplifying the experience so that we can all have many lives all at the same time and understand our key responses to life all the better for having been other where, being other people and other beings.

PVA: Theo, you have recently translated Lorca's poetry into Irish (Bailéid Giofógacha, 2019) ${ }^{7}$; and occasionally, you interweave English and Irish in your poems (i.e. "Begin,

7. Federico García Lorca, Bailéid Giofógacha [Romancero Gitano], Theo Dorgan (trans.), Baile Átha Cliath, Coiscéim, 2019. 
Begin Again”, from Greek, 2010; “"The Lost Gaeltacht of Lower Manhattan” and "Crossing the Border", both from Nine Bright Shiners, 2014). Nevertheless, although you are a fluent speaker of Irish, you prefer to write in English. Would you like to comment on this? Have you ever thought about writing poetry in Irish?

TD: I had this conversation with the great late Ciaran Carson, who had very good Irish but who also never wrote in Irish. We both felt that refraining from writing in Irish was a gesture of respect towards people who had immersed themselves completely in that language (and that's a heroic thing to do, to devote one's entire life to work into a language which is under such serious threat). My grasp of English is more than sufficient for whatever needs I have or I may have. I have a deep background in poetry in English, but I don't have the same full time immersion in Irish. I think it would be disrespectful to people who have made that commitment. I thought very hard about translating the Romancero Gitano into Irish, and then I decided that perhaps it was time to loosen up, to at least see if I could do it, without any further commitment to writing in a language that, after all, had a large part in shaping my young mind.

\section{PVA: Is there any other translation of Lorca's Romancero?}

TD: Into Irish? I don't think there is one of the full collection, but I may be wrong. You see, you have put your finger on it: I can't be sure. I can certainly tell you if there are translations into English of Lorca by Irish poets but I can't be sure about Irish because I don't have the same deep immersion in the language and the literature. I did all my schooling in Irish; all my education was through Irish and translating the Romancero is like a humble step back into the language. But I had to learn many new words; I had to examine my constructions and I had to have my grammar corrected. It was a journey back into a language that was once a very important daily part of my life but which by the time I came into eighteen and left school was no longer my daily language; it was floating further away from me. At that stage, I knew I was more fluent in English than I was in Irish; I knew I had read more deeply in English than I had in Irish. When I came to be eighteen and I had to make a choice, I decided to do only English at the university; I decided not to do both. I could have made the decision to turn into Irish, but it had implications that didn't appeal to me at that age. English seemed to me to have more expansive possibilities at the time: I had American English, Canadian English, Australian English, Scottish English, Indian English, Welsh English, Caribbean English, all available to me... I had all those domains of English to travel and I had a contracting domain in contemporary Irish and a finite history in the language. English seemed to me to have more expansive possibilities for a very restless eighteen-year-old than Irish did. It is possible that I made the wrong decision; I can't possibly tell. It wasn't out of lack of respect for the language, but a curious love for it. Whatever urge I felt to express my sense of being alive, I was more drawn into English.

8. Theo Dorgan, Greek, Dublin, Dedalus Press, 2010.

9. Theo Dorgan, Nine Bright Shiners, Dublin, Dedalus Press, 2014. 
PVA: As we briefly commented earlier, your poetry exhibits a profound fascination with Greek mythology, and indeed, you have been travelling to Greece on a recurrent basis for the last thirty years or so. What came first: your fascination for the landscape or for the myth? How and when did you become interested in Greek mythology?

TD: The interesting thing about Greek mythology is that it has permeated, like ground water, into all our separately defined cultures. Orpheus and Eurydice is a myth known in Portugal, Norway, Sweden, just as much as it is known in the Latin countries. It is part of our common European inheritance. So when Carol Ann Duffy decided to put together an anthology of favourite poems by certain writers and she asked me to nominate a favourite poem and write a response, I chose Cavafy's "Ithaca" (in particular, the translation by Philip Sherrard). I started thinking of Odysseus and about how it is the journey that matters. He took seven months to get to Troy and either ten years or twenty years (depending on how you read it) to come back home. He wasn't in a great hurry to get home and go back to the farm. I imagined Penelope dead, and his son Telemachus gone off to live his own life. What was Odysseus going to do? He was not going to sit down there and grow old looking at his sheep and his goats. So he made a little boat and sailed out again, because a voyager is always a voyager. I just liked that idea. At the end of his life, he had to make a boat and go away. He could turn back if he wished, but he was drawn to the call of the sea.

PVA: You have just mentioned Cavafy and this leads me to my next question. When you engage in a creative dialogue with Greece through ancient myth, sometimes you do it through contemporary poetic voices (i.e. Cavafy and Seferis) and some other times, it seems to me, through Homer's The Odyssey. When resurrecting Greek myth, which sources do you prefer? The classical ones or the modern revisions? TD: You give me credit for far too much scholarship and intelligence, Pilar... My poems are prompted by reflections in an ordinary day to day life, by the accidents and circumstances of my own life. The mind or the heart goes travelling and finds a temporary nesting place in the branches of the myth. You don't examine the myth with scholarly attention in order to make the poem fit the dimensions of the myth. The myth is a scaffolding and who knows in any real sense whether Orpheus was motivated by utter selflessness or by a possessive impulse when he looked back to see whether Eurydice was following him from the Underworld. There are all these possible human situations and a myth is certainly a scaffolding to hang on, so that we can tell the story. But I also know that we are at a moment in history when the uncontested view of the strong man who rescues the weak woman has been all but demolished, so it is possible then to go back to the myth and write the story, the narrative of the myth, in a completely different way. In a hundred years time, somebody may come back to the story of Orpheus with a perspective that we haven't even thought of yet. What I love about myth is its absolute capacity to allow us to project, to tell stories about ourselves in the light of the myth while not undermining the basic structure of the thing. 
PVA: Indeed, with respect to Greek mythology, your poetry is populated by figures such as Orpheus, Eurydice, Odysseus, Penelope, Telemachus, Artemis, etc.

TD: I know I am also skating over the surface of myth. I am just a traveller in the country, not an inhabitant or a citizen...

PVA: But not a tourist either...

TD: Well, I hope not...

PVA: Exactly. So you are not entirely surfacing...

TD: It is indeed in Greek myth, these days, that I find my "other where". Maybe Greece - and Russia before that - is simply an analogue for that otherworld? They give me a concrete place to find that sense of otherness that appeals so much to the travelling soul, as Buddhism puts it. This is a very austere perspective that appeals to me very strongly ever since I was a small child. We are a point of view, a travelling point of consciousness.

PVA: So what is it about Cavafy that you like so much?

TD: I think what I like about Cavafy is his sense of instructed melancholy. There is clearly a melancholic air in his work. It is the sadness of the world, but not an overwhelming sadness; it is not sorrow only, but it encompasses sorrow.

PVA: But this sadness does not mean lack of action; it is not a passive melancholy. TD: No; it is just another mode of engagement. I may have a melancholic temperament; it may be as accidental as that... And I have this sense of being in the world, but not quite of it. I always felt that, even as a child. In the prose piece "Home" I wrote for a book edited by Lucy McDiarmid and Rhona Richman Kenneally (The Vibrant House ${ }^{10}$ ), I went back to being ten, as I was sitting on the steps outside my family home. I remember distinctively this voice telling him, "remember this, you will need to remember this". That was Theo telling him that, and here I am, sixty years later writing about him, telling him those words. I tell you truly, Pilar, there is some place in myself that has never felt at home here, that has never taken the world as other people seem to have taken it. I love the material fact of the world but I also know that a solid world is just a field of electrons; it is simply a manifestation of energy; the entire universe is just energy.

PVA: So, there is something in the afterlife. There is something spiritual which is bigger than us.

TD: Not spiritual, at least not as we have the term as a cultural inheritance. This is perhaps more like non-material materiality. There is only energy and nothingness. And out of that framework we tell stories to help us feel less alienated, to help us feel at home.

10. Theo Dorgan, "Home Is Where You Start from", in The Vibrant House: Irish Writing and Domestic Space, Rhona Richman Kenneally, Lucy McDiarmid (eds.), Dublin, Four Court Press, 2017, p. 62-69. 
PVA: But energy never disappears...

TD: No, it does not. You are right. I don't believe in reincarnation (in the sense I will come back to earth as this present self) but I allow for the possibility of return, or continuance. The fascination for me is, what is it that it is paying attention to all this; what is the point of consciousness? I know that somewhere buried in my awareness is an awareness that this is all a fizz of energy and that it could be cancelled in a moment.

PVA: But we are all creators as well of all this energy, not simply recipients of it. TD: Yes, when I create a poem, it is a box full of energies...

PVA: In your literary reading at the university yesterday, you said something related to this and which made me think of Orpheus, the magician poet: "We don't make poetry; poetry makes us". So that sentence in a way is allowing the possibility of something bigger than us.

TD: That tree over there intends itself; the tree expresses itself as a tree; the stone expresses itself as a stone; the river expresses itself as a river. Everything is in process and is constantly manifesting and that manifestation is the meaning. What is the meaning of a tree? A tree! What is the meaning of a poem? A poem! We are curious creatures, we humans, because we want to break it down and we want to explain it and we want to ask questions. That is why poets have always needed scholars, and scholars have always needed poets. The poems manifest by means of the work of the poets, and the scholars ask questions about it, about the process and its products. Unfortunately, to get to scholarship these days you have to go through a strange manifestation called academia. So we have scholars, academics and makers. And the academics get between the scholars and the poets. Academics want to explain a thing away; the scholars want to uncover layers of meaning...

PVA: Is it not the same thing?

TD: No; what I mean by the academic is someone who wants position in the university, in the hierarchy of other academics, status among peers. For mischief, I have proposed that the patron saint of academics is Procrustes: if something does not fit the theory, they cut the legs off or they stretch it. I mention this in an essay "Southern Wind" 11 which got me into trouble with some academics. You have, at this moment in the culture, the supremacy of theory in literary discussion. Most critical attention to Irish poetry in the last twenty years has been a feminist and postcolonialist discourse, under the aegis of theory, so there is a poverty of discussion of, say, Peter Sirr, Thomas McCarthy and so many male poets of the same generation who are not receiving scholarly attention because at the moment in academia the way to get the job is to write about particular poets and not others.

11. Theo Dorgan, "Southern Wind", in Post-Ireland? Essays on Contemporary Irish Poetry, Jefferson Holdridge, Brian Ó Conchubhair (eds.), Winston-Salem, Wake Forest University Press, 2017, p. $289-306$ 
But there have always been scholars, people who have trusted their own sensibility, and who say "I find this work intriguing; I can see where it fits in a particular tradition; I wonder what that means in the poem", and that is absolutely valuable to the poet. You have told me things about my poetry that I was not aware of... Sappho, for instance; she is the sole remaining woman poet we know of from the archaic world but there must have been many others. Nobody is interested in the fact that she had a child; but, how did she get to have a child? They didn't have artificial insemination in classical Greece. Sappho has been confined, crudely, under the label "poet who loved women", and is written of in that light, but there is much more to her poems; but what are we to make of the fact she must also, at some stage, have used or loved a man. Otherwise, Cleis, her daughter, would not have been born. Isn't it interesting that nobody wants to talk about that? I had been thinking about this, just in a lazy kind of way, and I found myself sitting on a balcony in Chios, when literally, and this is literally true, this guy starts murmuring in my ear; this random sailor that she took to bed to give him a daughter and then sent off on his way. And he is telling me the story, and I am writing as fast as I can, listening to him. And it suddenly stopped. I went home and about two months later, as I was sitting on my desk with nothing to do, he suddenly came back with the second half of the story.

PVA: And the result is your wonderful collection Sappho's Daughter (1998). Was the process of inspiration similar in the case of your latest work, Orpheus (2018) ${ }^{12}$ ? TD: In Orpheus, I was thinking idly about Sapphic meter. God only knows what put that in my mind...

PVA: For a poet writing in English that meter must have been difficult, or at least a real challenge.

TD: You are leaping ahead exactly to what I was about to say. There are meters which work best in particular languages. I was wondering if Sapphic meter would do a particular kind of job when writing back into the archaic world in English, so I wrote a trial piece, as I thought, but then the book just took off. Then, right from the start, the book split off into two sections; Orpheus as a contemporary artistic figure and the reborn Orpheus in ancient times. I wrote the poems in those two parts simultaneously, left-hand-right and then left-hand-right; so the parts in the first section mirror the parts in the second one.

PVA: Oh, really? I didn't know that!

TD: Yes, they are absolutely mirrored... It is a way of saying that the Orphic impulse, the lyric impulse, is undying. Look, I was delighted when Bob Dylan got the Nobel prize; I was delighted because it was a celebration of the Orphic singer: poetry sings; poetry is its own music... So the two parts are mirrored at the emotional level. You can be looking at the dissolution of young new Orpheus, the disintegration

12. Theo Dorgan, Orpheus, Dublin, Dedalus Press, 2018. 
of his relationship, and you can also visualise him as he is floating like a starfish thinking about Eurydice, and saying "I loved you but not enough". But the two parts are not intellectually mirrored; they are more emotionally mirrored. They are not meant to be read together; they are two separate coherent narratives in time that mirror and echo each other.

PVA: As you were adjusting to the Sapphic meter, did you find that constraining at times?

TD: Can you tell a story of the old times, evoke that sensibility in the modern world, in a different language, with the meter carried on in a different language, or is it a meter that only works in Greek? I thought this was an interesting question. I had only occasionally written in strict meter before. I normally write fairly free verse. Usually my poetry has a pulse going through it, or a syllabic call sometimes, but it is generally written in free verse. So when I got into this I described it as "a liberation into form". Years ago I wrote a libretto Jason and the Argonauts (2014) which was commissioned by the Royal Albert Hall in London. They had rebuilt the organ and they asked the English composer Howard Goodall to write music for the whole range of the organ. I wrote this libretto based on the version of the story by Appolonius Rhodos offered by Robert Graves in The Greek Myths. I wrote it with a pentameter line when the boat is rowing and the hexameter line when the boat is sailing. I found that interesting, but then I turned back to free verse again. Until Orpheus came calling.

PVA: Again, you go back to ancient Greek mythological stories such as Jason and the Golden Fleece... Why do you never mention Irish mythology?

TD: I think we reach for myth to steady ourselves on our own journey and my journey does not involve fighting under arms for visions of Ireland or ideas of Ireland, and basically that's what our old stories are, paradigms of armed struggle. I must say there is nothing in my life that makes Cuchulain, for instance, an appealing figure...

PVA: But there are many other myths that you could identify with....

TD: But that's the key one.

PVA: Is there no equivalent to Odysseus in Irish myth?

TD: No, though we have the Immrama.

PVA: Or to Orpheus the magician poet?

TD: Well you have the Tuatha, shape changers, but other cultures have those: shape changers, seers and voyeurs. I find far more sympathetic figures in the Greek stories.

PVA: Do you have a record of the first time you were fascinated by Greek myth?

TD: I was always fascinated by the Mediterranean. There was a book that we all read when we were ten or eleven: The Wind in the Willows by Kenneth Grahame. Certain phrases in this book captured my imagination as a child. The water rat, going always up and down on the river; he is visited by his cousin the seafaring rat 
who rhapsodises about sailing in the Mediterranean. All whitewashed houses and covered lanes leading down to small harbours and the wine barrels rolling down the covered lanes and being loaded on board ships. And I thought: "Yes, take me away with you!". I loved dreaming those small little steep villages on the edge of the sea with sailing boats sailing off to who knows where with barrels of wine. It was so exotic and it also seemed strangely familiar.

PVA: Well, obviously Cork is a sea city...

TD: Yes; it seemed somehow familiar. I had that strange sensation while reading the work of feeling the sun on the back of my neck... I am not going to say I was there before, but there was that sense of being called by something half known.

PVA: Are you still sailing?

TD: On and off. It has been a couple of years. The last trip was Iceland to Dublin; it took us nine days.

PVA: I presume you go with an expert crew because you are not a professional sailor, right?

TD: But I can be trusted on a boat. You can go to sleep and leave me in charge...

PVA: I like very much the "Sea" sequence in Nine Bright Shiners (2014)... There are powerful poems there about the Skellig islands and the monastic ruins...

TD: You know, there is a $6^{\text {th }}$ century cross in the Westman Islands, off Iceland, put there by Irish monks? Speaking of that collection [Nine Bright Shiners] the reviewers so far have missed the intertextuality in it. The middle section "Chorus", for instance, has not been fully understood. "The Child I was Regards the Infinite" is written after Leopardi; "She Travels in Winter" is after Hopkins (particularly the sound text of it); "Insomnia" is after Emily Dickinson (when I was a child, I loved the rhythm of her poem "Because I Could Not Stop for Death"). The character of Lena Stakheyeva in "The Love Poems of Lena Stakheyeva" is completely imagined; she was a character in a novel I ended up shelving. "What Wonders" is written after John Berryman's Mr. Bones in the Dream Songs and it is written as a Berryman sonnet. These are gestures towards colleagues and their craft.

PVA: This explains the title of the section, "Chorus", an amalgam of literary antecedents and imagined future poets, right?

TD: Indeed; it is literally a chorus. It is like saying, "here are all these different sensibilities and we can be all those different sensibilities; we are influenced by them, they have an effect on us, and they come back to us in different forms". The poem "The Senator on the Feast of Saturn" is like a choric song from the ancient world:

Blood and rough wine in the sand the sandal beating the sand and blood on the dancer's hands the rough wind drenching her hair 
And the beacons lit on the promontories the old gods in the wood by the shore the bronze axe in the block and the flat stone where the god stood ${ }^{13}$.

You can hear the lines being chanted; that was originally what a choric song was like. This section "Chorus" could have been called "Being Other". In my case, the easiest way to "be other" is as a woman, or a crow, a raven, a tree, a dryad.

PVA: This sense of ventriloquism has always been in your work. In Sappho's Daughter, for instance, you constantly change voices between Sappho and her male lover... TD: This is what I meant earlier before when I said that we don't write poems, the poems write us. There is a very short poem by Robert Graves that I profoundly admire; it is called "Dance of Words":

To make them move, you should start from lightning

And not attempt to forecast the rhythm:

rely on chance or so-called chance for its bright emergence

Once lightning interpenetrates the dance.

Grant them their own traditional steps and postures

But see they dance it out again and again

Until only lightning is left to puzzle over -

The choreography plain, and the theme plain ${ }^{14}$.

I have a strong sense of the ongoing dance; you are in conversation with previous poets and you are nurturing a new generation of poets. We are all inscribed in the dance. It's a tribal thing, if you like. My tribe is the ancient and honourable tribe of storytellers. This also applies to scholars (there is an ancient and honourable tribe of scholars), and also to gardeners, public rulers, engineers...

PVA: So it is basically an act of recognising that you are part of a community; that you are not only an individual voice...

TD: Yes; but it is also an act of empathetic relations with certain people such as Hopkins or Dickinson who share a certain sensibility with you, if only slightly. You can pull back a rhythm from them, a verse form, a set of related images. It is not that you can make them your own, but you can inhabit them for a while, and you can play with them. Most of it is playing with them; it is messing around...

PVA: This is the collective voice of a Greek chorus...

TD: Yes; I placed this section in the middle of the collection to break down the idea that I am trying to impose a sensibility on the reader. I want you to think of me as "other" when you are reading the book...

13. Theo Dorgan, “The Senator on the Feast of Saturn”, in Nine Bright Shiners, p. 92.

14. Robert Graves, The Complete Poems, Beryl Graves, Dunstan Ward (eds.), London, Penguin, 2003, p. 542 . 
PVA: So you want to undermine the idea of authorship in a way...

TD: Not to undermine it, no, perhaps to situate it...

PVA: Let me link this with the review that Thomas McCarthy (2014) wrote of Nine Bright Shiners, where he claims that, unlike younger poets, you sustain a view of community and "communal remembrance" in your work:

Dorgan belongs to a generation of writers - novelist Roddy Doyle and playwright Billy Roche would be his companions - who see the world through unapologetic and unreconstructed Left-wing spectacles. There is a strong political sense in these poems that the poor shall inherit the Earth and that poets, somehow, will one day own all the means of production. Dorgan's is a generation of intellectuals radicalised by Herbert Marcuse and Jean Paul Sartre, illuminated by Costa Gavras and bewitched by Pablo Neruda and Gabriel Garcia Marquez. Newer generations of Irish writers, those reared in a private, ironic world (so private that they are outraged by the free gift of a $\mathrm{U} 2$ album) could never understand the massive optimism contained within Dorgan's unbroken sense of community. Such a belief in political community is, in a very real sense, an affront to the modern ${ }^{15}$.

Would you agree on this?

TD: That is classic McCarthy, racing away with his own enthusiasms, but I don't recognise myself in much if any of this. Roddy Doyle does not like poetry and he deliberately writes in flat contemporary English. Marcuse I never read. I do love Costa Gavras's films, and also the work of Neruda and Marquez, but all for reasons different to those that McCarthy imagines here. He is projecting himself into this review, generously but misleadingly.

PVA: But would you agree that, in comparison to younger generations of writers, there is a stronger sense of communal sensibility in your work...

TD: Well, I think I have more of an affinity with Eavan Boland than with Roddy Doyle. My work has a kind of conversation with Eavan that it doesn't have with Roddy; and it has a conversation with Paula Meehan that it doesn't have with Billy Roche. My sense of community is different from that envisioned in the work of Doyle or Roche. This is not only an Irish community; I also have the same communion with the dead. I went sailing to Nazaré in Portugal; it was as if I travelled with Orpheus in the Argo. I wrote in Time on the Ocean ${ }^{16}$ of a night when we were getting 80 mile an hour winds, with 12 meter waves, and we were knocked over by a 14 meter wave, putting the mast briefly in the water; to me that's being in the same place as the storm towards the end of Jason and the Argonauts, the Argo is battered by a huge seas and howling winds. It is the same experience, just differently

15. Thomas McCarthy, "On the Voyage of Life, All That Finally Matters is 'Fellow-Ship", Irish Examiner, 1 November 2014, on line: https://www.irishexaminer.com/lifestyle/artsfilmtv/books/ on-the-voyage-of-life-all-that-finally-matters-is-fellow-ship-295684.html.

16. Theo Dorgan, Time on the Ocean, Dublin, New Island, 2010, p. 92. 
expressed. When I am in a poem, I am out of time; there is only the time of the poem. The poem is a release from the tyranny of linear time, into true time. There is such a thing as true time. When you met your beloved child (Pablo), what was time then? You could look at it forever. How much time has passed while you were gazing at the child? When you met your husband and you fell in love; what was that? You fell in love...

PVA: You are talking about moments of transcendence...

TD: Transcendence is used as a synonym for ecstasy. And what is ecstasy? Ex stasis, to stand outside... Not to be dead... A normal life carries on; you are standing outside and looking at it from a different perspective. Anyone who has ever had a lover knows that moment when, making love, there is a point in which time stops; time becomes "other". You are still breathing, your heart is still beating, but you are somewhere else, and that somewhere else is also here. That is what a poem proposes; that elsewhere is also here. And this here is also elsewhere.

PVA: I like your concept of time in this marvellous poem which closes Nine Bright Shiners, "Envoi: Cape Horn": "we ride the wind a moment, a moment only, / but the better truth is this: time is eternal now, / there never was, nor ever will be, an end to voyaging" ${ }^{17}$.

TD: Yes. Time is eternal now, and perhaps the secret of the poem is that it allows us to experience this, but we are obliged nonetheless, in human solidarity, to pay attention to the linear lives that we live, the responsibilities that we have in the world. So Orpheus tries to be true to his gift but he also knows someone has to clear out the cellar; someone has to polish the glasses for the customer; someone has to arrange the water to tend the vines...

PVA: What are you working on at the moment?

TD: In May I wrote a long sequence of poems about being in primary school. I have got two thirds of the way through it, but I haven't been able to look at it since then; I haven't had time.

PVA: Are these your school experiences while growing up in Blackpool?

TD: Well, yes; I was brought up in Blackpool but I went to school in the North Monastery, as did that fine poet Gerry Murphy. And Michael Davitt, of course, a major poet in Irish. The poems are very crude and unshaped at the moment; I am feeling my way into them, but it seems to be about tracing how his mind was shaped. I am thinking of "him" not "me"...

PVA: So, you need this sense of detachment to write about your younger self...

TD: Well; it is not an intellectual decision; I just keep thinking of "him" as "him"; like a specimen under a microscope. I am writing about cruelty and alienation.

17. Theo Dorgan, “Envoi: Cape Horn”, in Nine Bright Shiners, p. 142. 
The shift from the convent where all the teachers were women into the much more repressive atmosphere where all the teachers were men, Christian Brothers and lay people. That was a clipping and a cutting back; it was a place of anti-imagination, anti-feeling, anti-emotion. But his grasp of language is increasing each time and also his capacity for occasional moments of abstract thought, when he looks at a teacher and says "you are enjoying frightening us"...

PVA: Was there physical abuse involved as well?

TD: Yes; we were always beaten; every day we were beaten on the hand.

PVA: Would you say this is your most autobiographical writing so far?

TD: Yes; I was thinking of writing a prose memoir and then these poems started to come in and I thought I would go with it and see what happens. I was interested in seeing how his mind was formed; how did he come to have this mind of mine; what happened when he was young that shaped this particular mind that I have now. All the other boys were playing football, and apparently all right with what was happening around, but he was examining his situation and thinking "You shouldn't be doing this to me".

PVA: So you already had a sense as a child that what you were living through was not the right thing.

TD: Yes, indeed. He was telling himself "Pay attention to this; you will need to have remembered this. You will have a responsibility to remember this". I owe a debt to that child; that child made me promise not to forget him.

Granada, 9 November 2019

Pilar Villar-ARgáiz University of Granada (Spain) 